【カテゴリーII】

約 5 年間の実測データに基づくコンクリートのクリープ・収縮寸法効果の評価と クリープ予測方法の提案

\author{
AN EVALUATION OF CREEP AND SHRINKAGE SIZE EFFECTS BASED ON \\ ABOUT FIVE YEARS MEASUREMENTS AND A PROPOSAL \\ OF PREDICTION MODEL FOR CONCRETE CREEP
}

\author{
今本啓一*, 山本俊彦**, 大岡督尚*** \\ Keiichi IMAMOTO, Toshihiko YAMAMOTO and Tokunao OH-OKA
}

\begin{abstract}
It is well known that size of concrete member strongly affects its creep and shrinkage behaviors. In this study, creep and shrinkage strains of 50 and $130 \mathrm{MPa}$ concretes in various size square columns were measured for about 5 years. The effects of size on shrinkage and creep were discussed through comparisons between the observed values and the calculated values by CEB-FIP 1990 and JSCE model codes. The results showed that these models, especially CEB-FIP 1990 Model Code (MC90) codes, could evaluate the relative changes of creep and shrinkage due to specimen size. This might indicate that the combination of accurate shrinkage and creep evaluations of reference specimen (Ex.10cm square column) and the size effect factor of MC90 enables the correct evaluation of shrinkage and creep of various size square columns. In this paper, a revised MC90 adjusted to creep data in Japan was also proposed.
\end{abstract}

Keywords: shrinkage, creep, size effect, column, high strength concrete, long-term measurement

収縮，クリープ, 寸法効果, 柱, 高強度コンクリート, 長期測定

1.はじめに

コンクリートのクリープ・収縮による時間依存変形はコンクリー ト自体のひび割れ発生の主要な原因であるのみならず，たわみ等， 構造物の長期的な使用性にも影響を及ぼす重要な要因の一つである。 このため,これらクリープ・収縮予測のための式が提案され ${ }^{1,2), 3)}$, 一部 実用に供されているものもある ${ }^{1,2)}$ 。この分野で蓄積されている多くのデ 一夕は小型の試験体を用いて得られたものであり，予測式もこれらデー 夕に基づいて構筑されたものが多い。したがって,これら予測式を用い る上で実大部材との関連を検討することは実用上きわめて重要であるが, この種の検討は必然的に大規模な実験に基づかざるを得ないため，小型 の供試体と比較した研究例は極めて少ないのが現状である ${ }^{4,5,5,6) 7 。 ~}$

T.C.Hansen らは ${ }^{4)}$ 普通強度レベルのコンクリートを対象とし, 直径 4 〜24インチの円柱供試体, 11.5x4.25〜46x17 インチのI型供試体の材齢 4 年にわたるクリープ・収縮ひずみを測定した。ここでは，長期的なクリ 一プ・収縮に及ぼす部材寸法の影響は極めて大きく，さらにその影響は 部材の体積表面積比で統一的に評価できることが示されている。また， A. H. Bryant らは ${ }^{5)}$, 普通強度レベルのコンクリートを対象とした約 6 年にわたるクリープ・収縮の実験データを整理し, AC1209 モデルコード はその影響を過小評価するとともに，同コードの時間関数項に部材寸法 の影響を考慮することによって実験值を精度よく追跡できることを示し ている。一方国内においては, 安田らにより普通強度レベルのコンク
リートを対象とした $10 \times 10 〜 80 \times 80 \mathrm{~cm}$ 部材の材龄 11 年までのクリープ・ 収縮測定が実施された。ここでは部材断面が大きくなるほどクリープは 小さくなるが，収縮ひずみについては，乾燥開始が 7,28 日では部材間の 差が小さいことが報告されている。桝田らわによって実施された 60 及び $100 \mathrm{MPa}$ 級の高強度コンクリートを対象とした $20 \times 20 \sim 60 \times 60 \mathrm{~cm}$ 部材の材 龄 1 年までのクリープ・収縮測定実験では, 強度レベルの高い方がひず み（弹性ひずみ+収縮ひずみ+クリープひずみ）の増進が小さいことが報 告されている。ここでは部材寸法の影響に関する詳細は報告されていな い。

以上のように，クリープ・収縮を包含したコンクリートの時間依存特 性に及ぼす部材寸法の影響に対しては, その研究例の少なさからも統一 的な見解が得られていないのが現状である。さらに国内の材料を用いた コンクリートのクリープ・収縮特性は必ずしも国外の予測式によって精 度よく評価できるとは限らないとの報告もあり ${ }^{8)}$, 今後, 本分野におけ るこの種のデータを蓄積することはきわめて重要と考える。

本研究では, 50MPa, 130MPa 級の 2 種類の強度レベルのコンクリート について, $10 \times 10 \mathrm{~cm} \sim 50 \times 50 \mathrm{~cm}$ を中心とした最大 $450 \times 1300 \mathrm{~cm}$ までの種々 の断面寸法の試験体の約 5 年間にわたるクリープ・収縮ひずみ測定を実 施した。本論はその結果に基づき，クリープ・収縮ひずみに及ぼす部材 寸法の影響について検討を行い，特に広範囲な部材寸法に対応するクリ ープ予測への道筋について提案を行うものである。
* 足利工業大学工学部建築学科 講師・博士 (工学)

** 大同工業大学建設工学科建築学専攻 教授・工博

*** 束急建設侏技術研究所 主任研究員・博士 (工学)
Assist. Prof., Dept. of Architecture, Ashikaga Institute of Technology, Dr. Eng. Prof., Dept. of Architecture, Faculty of Construction, Daido Institute of Technology, Dr. Eng.

Senior Research Engineer, Institute of Technology, Tokyu Const. Co., Ltd., Dr. Eng. 


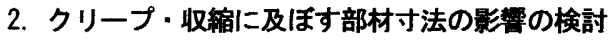

\section{1 实験概要}

\section{1.1 使用材料及び計画調合}

本研究で使用したコンクリートは，強度レベル 50MPa，130MPa 級の 2

種類である。それぞれの使用材料及び計画調合を表 1,2 に示す。 表 1 使用材料

\begin{tabular}{|c|c|c|}
\hline & $50 \mathrm{MPa}$ & $130 \mathrm{MPa}$ \\
\hline $\begin{array}{c}\text { セメント } \\
\mathrm{C}\end{array}$ & $\begin{array}{l}\text { 普通ポルトランドセメント } \\
\text { 密度 } 3.16 \mathrm{~g} / \mathrm{cm}^{3}\end{array}$ & $\begin{array}{l}\text { 早強ポルトランドセメント } \\
\text { 密度 } 3.14 \mathrm{~g} / \mathrm{cm}^{3}\end{array}$ \\
\hline 細骨材 S & 川砂 密度 $2.57 \mathrm{~g} / \mathrm{cm}^{3}$ & 川砂 密度 $2.60 \mathrm{~g} / \mathrm{cm}^{3}$ \\
\hline 粗骨材 G & 硬質砂岩砕石 密度 $2.60 \mathrm{~g} / \mathrm{cm}^{3}$ & 石英片岩砕石 密度 $2.63 \mathrm{~g} / \mathrm{cm}^{3}$ \\
\hline 混和材 SF & - & $\begin{array}{l}\text { シリカフューム } \\
\text { 密度 } 2.2 \mathrm{~g} / \mathrm{cm}^{3}\end{array}$ \\
\hline 混和剂 Ad & $\mathrm{AE}$ 减水剤 & $\begin{array}{l}\text { ポリカルボン酸系高性能 } \mathrm{AE} \\
\text { 減水剂 }\end{array}$ \\
\hline
\end{tabular}

表 2 計画調合

\begin{tabular}{|c|c|c|c|c|c|c|c|c|}
\hline \multirow{2}{*}{$\begin{array}{c}\text { 強度 } \\
\text { レベル }\end{array}$} & \multirow{2}{*}{$\begin{array}{c}\mathrm{W} /(\mathrm{C}+\mathrm{SF}) \\
(\%) \\
\end{array}$} & \multirow{2}{*}{$\begin{array}{l}\text { S/a } \\
(\%)\end{array}$} & \multicolumn{6}{|c|}{ 単位量 $\left(\mathrm{kg} / \mathrm{m}^{3}\right)$} \\
\hline & & & W & C & SF & $\mathrm{S}$ & G & Ad. \\
\hline $50 \mathrm{MPa}$ & 45.0 & 45.9 & 157 & 349 & - & 827 & 994 & 0.87 \\
\hline $130 \mathrm{MPa}$ & 23.0 & 45.0 & 165 & 645 & 72 & 682 & 842 & 25.2 \\
\hline
\end{tabular}

\subsection{2 硬化コンクリート性状}

本研究で使用したコンクリートの压縮強度およびヤング係数を表 3 に 示す。

表 3 コンクリートの圧縮強度およびヤング係数

\begin{tabular}{c|c|c|c|c}
\hline & \multicolumn{2}{|c|}{28 日標隻水中養生 } & \multicolumn{2}{c}{28 日現場水中盖生 } \\
\hline 強度レベル & 压縮強度 & ヤング係数 & 圧縮強度 & ヤング係数 \\
\hline $50 \mathrm{MPa}$ & - & - & $40.1 \mathrm{MPa}$ & $28.8 \mathrm{GPa}$ \\
\hline $130 \mathrm{MPa}$ & $124 \mathrm{MPa}$ & $37.1 \mathrm{GPa}$ & - & - \\
\hline
\end{tabular}

\subsection{3 部材条吽およひ測定方法}

本研究で使用した部材の形状を表 4 に示す。

表 4 部材形状および条件

\begin{tabular}{|c|c|c|c|c|c|}
\hline $\begin{array}{l}\text { 強度 } \\
\text { レベル }\end{array}$ & 用途 & $\begin{array}{c}\text { 繸 } \mathrm{x} \text { 横 } \mathrm{x} \text { 長さ } \\
\mathrm{cm}\end{array}$ & $\begin{array}{l}\text { 軸方向鉄 } \\
\text { 筋比 }(\%)\end{array}$ & $\begin{array}{l}\text { ひずみ } \\
\text { 測定 }\end{array}$ & $\begin{array}{l}\text { 底力 } \\
\text { 強度比 }\end{array}$ \\
\hline \multirow{14}{*}{$\begin{array}{c}50 \\
\mathrm{MPa}\end{array}$} & \multirow{7}{*}{ クリープ } & $10 \times 10 \times 40$ & Plain & \multirow{12}{*}{ E.G ${ }^{* 3}$} & 0.15 \\
\hline & & $25 \times 25 \times 160$ & Plain & & 0.14 \\
\hline & & $25 \times 25 \times 160$ & 0.32 & & 0.14 \\
\hline & & $50 \times 50 \times 310$ & Plain & & 0.14 \\
\hline & & $50 \times 50 \times 310$ & 0.32 & & 0.14 \\
\hline & & $200 \times 1000 \times 800$ & 0.32 & & 0.10 \\
\hline & & $450 \times 1300 \times 1800$ & 0.32 & & 0.15 \\
\hline & \multirow{7}{*}{ 乾燥収縮 } & $10 \times 10 \times 40$ & Plain & & \multirow{7}{*}{0} \\
\hline & & $25 \times 25 \times 100^{* 1}$ & Plain & & \\
\hline & & $25 \times 25 \times 160$ & 0.32 & & \\
\hline & & $50 \times 50 \times 100^{* 1}$ & Plain & & \\
\hline & & $50 \times 50 \times 310$ & 0.32 & & \\
\hline & & $200 \times 1000 \times 800^{* 2}$ & 0.32 & S.F. $G^{* 4}$ & \\
\hline & & $450 \times 1300 \times 1800^{* 2}$ & 0.32 & S.F.G ${ }^{* 4}$ & \\
\hline \multirow{6}{*}{$\begin{array}{l}130 \\
\mathrm{MPa}\end{array}$} & \multirow{3}{*}{ クリープ } & $10 \times 10 \times 40$ & \multirow{6}{*}{ Plain } & \multirow{6}{*}{ E.G } & 0.28 \\
\hline & & $25 \times 25 \times 160$ & & & 0.26 \\
\hline & & $50 \times 50 \times 310$ & & & 0.28 \\
\hline & \multirow{3}{*}{ 乾燥収縮 } & $10 \times 10 \times 40$ & & & \multirow{3}{*}{0} \\
\hline & & $25 \times 25 \times 100^{* 1}$ & & & \\
\hline & & $50 \times 50 \times 100^{* 1}$ & & & \\
\hline
\end{tabular}

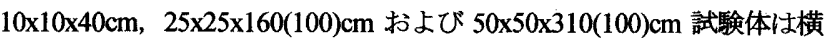
置きで設置された鋼製型枠に打設し，その収縮ひずみは，断面中心部に 設置された埋込み型ひずみ計 (Embedded gauge: E.G 表中*3) により測定 した。乾燥收縮測定開始材路令は 50MPa 試験体で 14 日, 130MPa 試験体で 28 日であり,その時点まで試験体上面は湿布養生とした。断面寸法 $25 \times 25$ および 50x50cm 試験体の端面は，乾燥防止の目的で，鋼板によりシール した（表中*1）。断面寸法 200x1000cm および 450x1300cm 試験体は反 力壁（応力導入は鉛直方向）であり，0.32\%の軸方向鉄筋が配置され ている。ここでは，上記の試験体（断面寸法 $10 \times 10 〜 50 \times 50 \mathrm{~cm}$ ）と同一 バッチのコンクリートにおける 1 筒所の計測值を用いた（計測位置 : 図

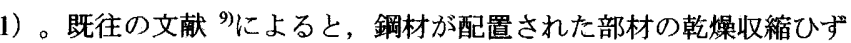
みは, 無応力計(Stress free type gauge: S.F.G 表中*4)によりおおよそ評 価できることが示されている。図 2 に示寸緊張力導入前後の無応力 計および埋込み型ひずみ計の変化について, 無応力計の測定値は, 载荷による変化が生じておらず，周囲の拘束の影響を受けていない と考えられる。以上より，本研究では，無応力計による測定值は， 無筋（Plain）状態の反力壁の乾燥收縮ひずみにほぼ相当すると仮定 した。なお測定開始（材齢 14 日）までは型枠を存置した。

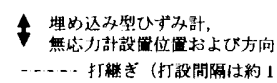
如中単位: cm

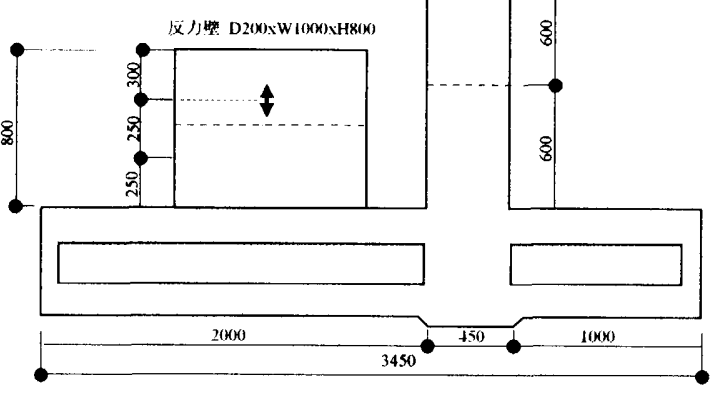

図 1 反力壁におけるひずみ計・無応力計埋設位㯰

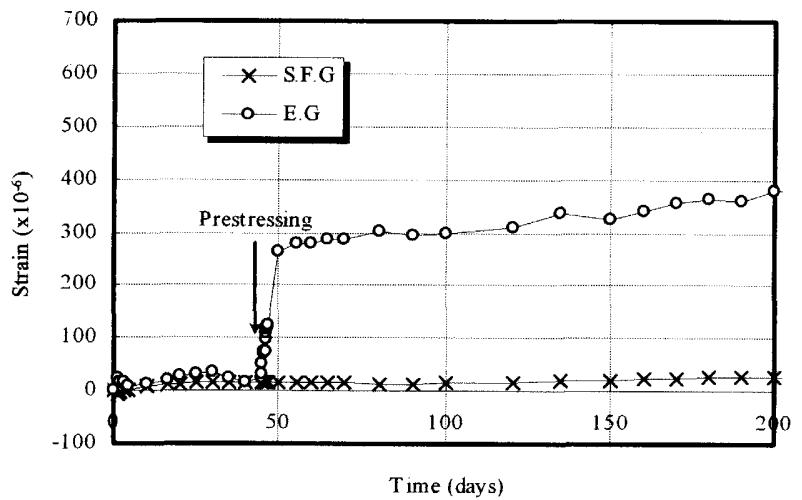

図 2 反力壁 $(\mathrm{D} 450 \mathrm{xW} 1300 \mathrm{~cm})$ におけるひずみ履歴

クリープ試験体の載荷開始材㱓は 50MPa 試験体で 41 日, 130MPa 試験 体で 28 日とした (50MPa 試験体は乾燥開始から載荷まで気中乾燥状態)。

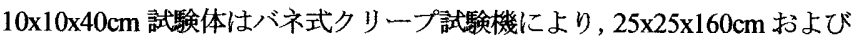
$50 \times 50 \times 310 \mathrm{~cm}$ 試験体は $\phi 32 \mathrm{PC}$ 鋼棒により，そして反力壁は $\phi 12.7 \mathrm{PC}$ ス トランド鋼線（450x1300cm : 29 本，200x1000：11 本）により応力を 導入した。なお， $450 \times 1300 \mathrm{~cm}$ および 200x1000 cm 反力壁の応力導入は 
それぞれ約 5 日および約 3 日を要している。本論のクリープひずみは載 荷完了以降のひずみを対象とし，埋込み型ひずみ計（E.G）の測定値か ら, 同一断面の無載荷試験体の収縮ひずみを差し引くことにより求めた。 反力壁については，無応力計（S.F.G）の測定值に，後述する鉄筋の影響 を考虑した值を差し引くことによりクリープひずみを求めた。

$10 \times 10 \times 40 \mathrm{~cm}, 25 \times 25 \times 160 \mathrm{~cm}$ および $50 \times 50 \times 310 \mathrm{~cm}$ 試験体の載荷応力は, ロードセルにより計測した。一方，反力壁における導入応力（ $\sigma(\mathrm{t}))$ は 載荷時の導入軸力を初期值とし, 反力壁コンクリートのひずみのロス分 が鋼材ひずみのロスであると仮定した下式により算定した。

$\sigma_{(t)}=\sigma_{(i)}-\Delta \varepsilon_{(t)} \cdot E_{s} \cdot A_{s} / A_{c}$

ここで,

$\sigma_{(i)}:$ 導入軸力 $(\mathrm{MPa})$

$\Delta \varepsilon_{(t)}:$ コンクリートのひずタロス（=鋼材ひずタロス）

$E_{s}:$ ストランドのヤング俰数 $(\mathrm{MPa})$

$A_{s}:$ ストランドの総断面積 $\left(\mathrm{cm}^{2}\right)$

$A_{c}:$ コンクリートの断面積 $\left(\mathrm{cm}^{2}\right)$

図 3，4 はクリープ試験における載荷态力履歴を示したものである。 $10 \times 10 \times 40 \mathrm{~cm}, 25 \times 25 \times 160 \mathrm{~cm}$ および $50 \times 50 \times 310 \mathrm{~cm}$ 圾験体については適宜導 入応力の調整を行っている。図に示すように，反力壁も含めた約 5 年間 の軸応力変動は 50 および130MPa クラスのコンクリート試験体でそれぞ れ 5 および $2 \%$ 程度となっており，概ね安定した応力の導入が図られて いるものと考えられる。

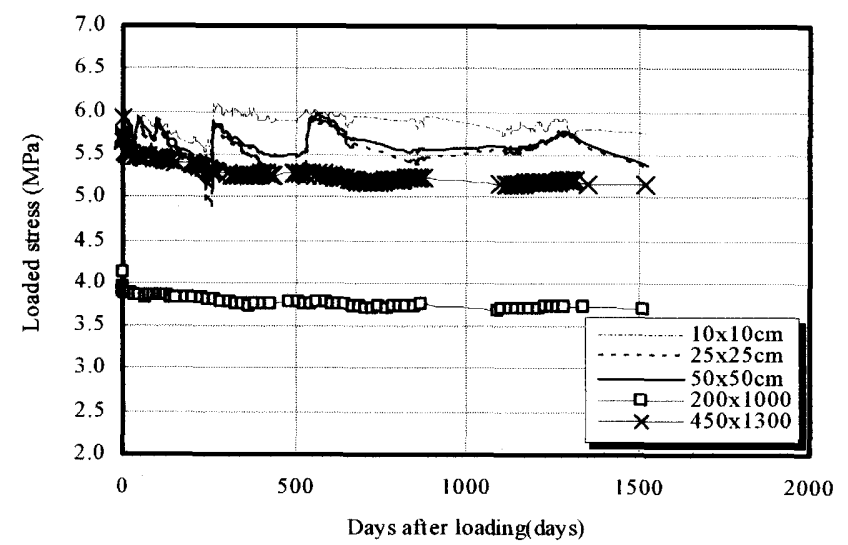

図 3 載荷応力履歴（50MPa）

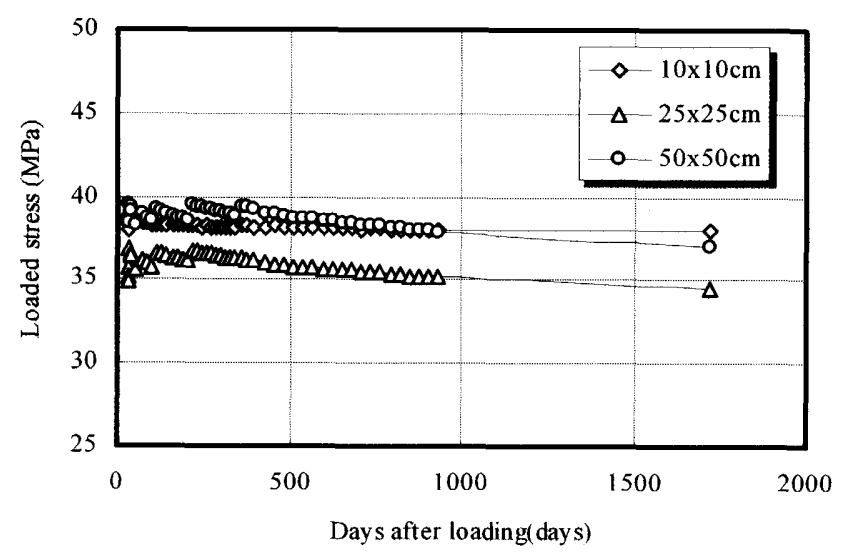

図 4 載荷応力履歴（130MPa）

\subsection{4 環境条件}

測定時における雲囲気温度, 相対湿度の変化を図 5,6 に示す。本実験 では，50MPa 試験体は雨撕かりの無い屋内，130MPa 試験体は公称 $20 \pm$ $3^{\circ} \mathrm{C}, 60 \pm 5 \%$ R.H.の恒温恒湿室内にて計測を行った。各条件における温 度, 湿度の変化を図 5，6 に示す。なお，50MPa 試験体の計測において は相対湿度の测定を行っていないため,ここでは雾囲気温度の測定結果 のみを示す。計測期間中の平均気温は $14.1^{\circ} \mathrm{C}$, 最高温度, 最低温度はそ れぞれ $31.0,2.1^{\circ} \mathrm{C} て ゙ あ っ た 。 130 \mathrm{MPa}$ 試験体における計測期間中の平均 気温, 平均相対湿度はそれぞれ $20.8^{\circ} \mathrm{C}$ (最高 $22.0^{\circ} \mathrm{C}$, 最低 $19.7^{\circ} \mathrm{C}$ )，55.9\% （最高 $59.7 \%$ ，最低 $52.0 \%$ ) であった。

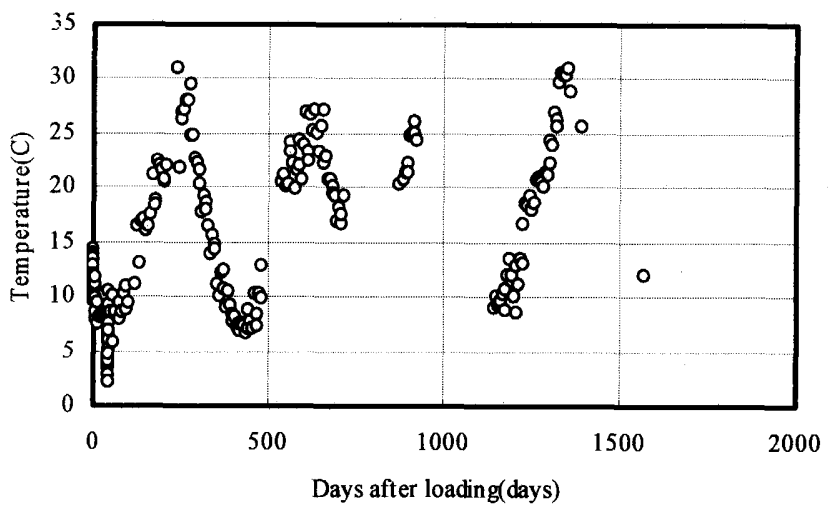

図 5 雲囲気温度の変化 (50MPa)

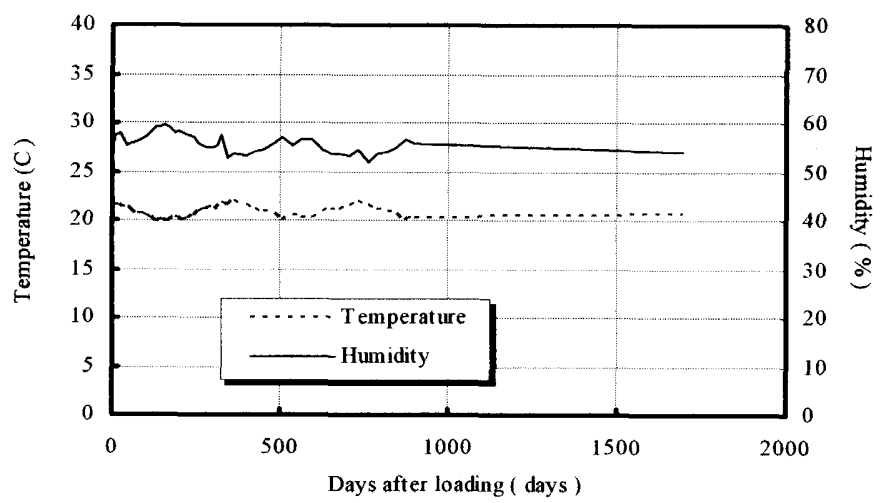

図 6 雾囲気温湿度の変化 (130MPa)

\section{2 実験結果}

\subsection{1 収縮ひずみ}

$50 \mathrm{MPa}$ 試験体の収縮ひずみ測定結果を図 7 に示す。図は型枠脱型（材 齢 14 日）以降の変化を示したものである。10x10x40cm 試験体の収縮ひ ずみは概ね脱型後材齢 500 日で安定し，25x25x160(Plain:100)cm および 50x50x310(Plain:100)cm 試験体の収縮ひず夕は概ね脱型後材路 1200 日で 安定している。鉄筋の拘束により有筋（Re-bar）試軩体の収縮ひずみは, 無筋（Plain）のそれと比較して若干小さく，その割合は約 0.8 である。 $450 \times 1300 \mathrm{~cm}$ 拉び 200x1000cm 反力壁の収縮ひずみは脱型後材齢約 1500 日の範囲内ではほとんど進展していない。脱型後材龄約 1500 日

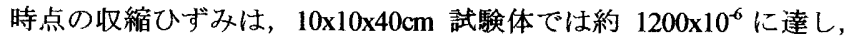

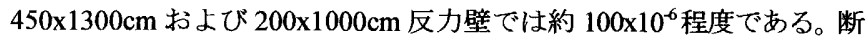
面寸法が大きくなるほど収縮ひずみが小さくなる傾向が顕著である。 同図には CEB-FIP Model Code1990（MC90）および土木学会普通強度 予測式（JSCE(N)）による計算結果が示されている。同式における相 
対湿度の入力值としては，近隣地区でこの期閒測定された相対湿度 の平均值 : $67.7 \%$ (最高 : $84 \%$, 最低 : 46\%) を用いた。いずれの式 も実測值を過少評価する結果となっている。

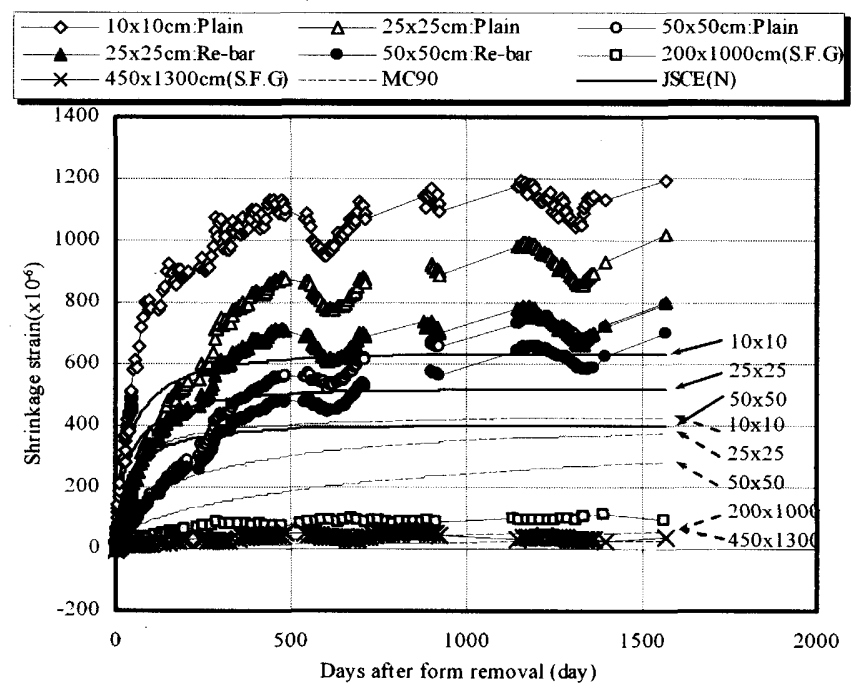

図 7 収縮ひずみの変化（50MPa）

$130 \mathrm{MPa}$ 試験体の収縮ひずみ測定結果を図 8 に示す。図はクリープ載

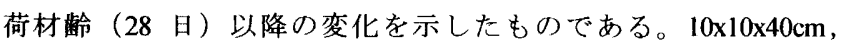
$25 \times 25 \times 100 \mathrm{~cm}$ および $50 \times 50 \times 100 \mathrm{~cm}$ 試験体とも，収縮ひずみは概ね脱型後 材龄 800 日で安定する傾向が見られる。10x10x40cm 試呀体の収縮ひずみ は脱型後材龄約 1700 日で約 $200 \times 10^{-6}$ であり，断面寸法が $25 \times 25,50 \times 50 \mathrm{~cm}$ と大きくなるにつれ収縮ひずみが小さくなる傾向が，本強度レベル においても認められる。同図には MC90 および十木学会高強度予測 式 (JSCE(H)) による計算結果が示されている。本強度はいずれの予 測式の適用範囲を超えたものであるため本結果はあくまで参考値と なるが，実測值に対するJSCE 式予測值は若干の過大評価, MC90 予 測値は若干過少評価となる傾向にある。

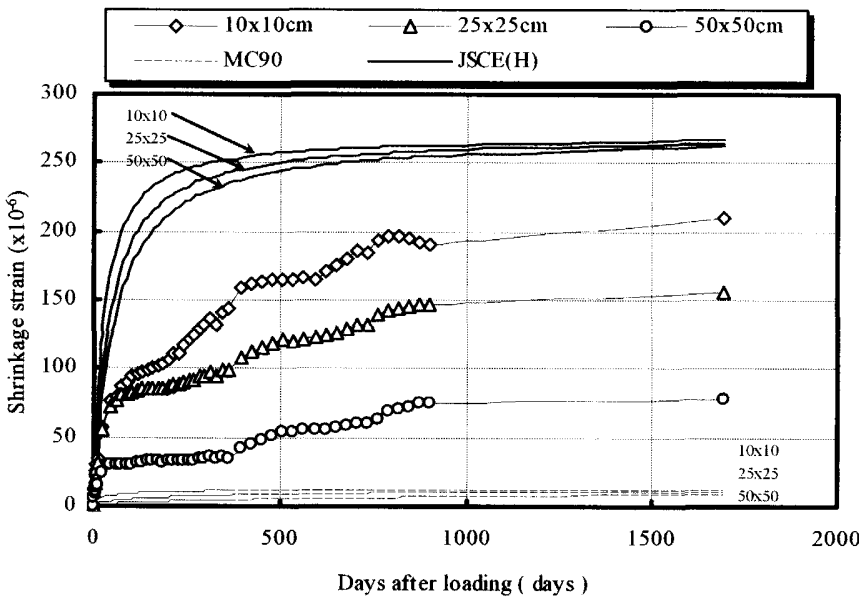

図 8 収縮ひずみの変化（130MPa）

\subsection{2 クリープ}

$50 \mathrm{MPa}$ 試験体の単位クリープひずみの測定結果を図 9 に示す。図は軸

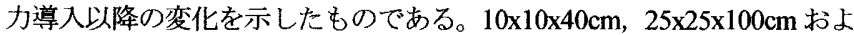
び 50x50x100cm 試験体とも，単位クリープひずみは載荷後材龄約 4 年を 経ても若下であるが漸増する傾向にある。10x10x40cm 試験体の単位クリ
ープひずみは載荷後材龄約 1500 日で約 $220 \times 10^{-6} / \mathrm{MPa}$ であり, 断面寸法

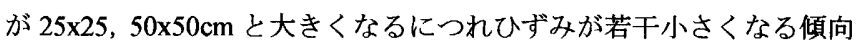
にある。鉄筋の有無による単位クリープひずみの差は顕著には認め られない appendix 。このことから, $200 \times 1000 \mathrm{~cm}, 450 \times 1300 \mathrm{~cm}$ 反力壁の クリープは，埋込み型ひずみグージの測定値から，鉄筋の影響を考 慮して, 無怘力計の值に 0.8 を乗じた值を差し引いて求めた。これに よると, 部材寸法の大幅な増大により, クリープが明らかに低下す る傾向が認められる。なお，同図には MC90 および土木学会普通強 度予測式 (JSCE(N)) による計算結果が示されている。同式における 相対湿度の入力值は, 前述の収縮ひずみのそれと同じ值を用いてい るが，いずれの式も実測值を過少評価する結果となっている。骨材 岩種などの影響が大きいものと思われるが詳細な原因は不明である。 MC90 について, 載荷後材齢約 1500 日の値を最終值とみなして実測 値にフィットさせた太曲線（Revised MC90）も表示した。断面の小 さな部材では外気温湿度の変化の変動により初期のひずみに乘離が 生じているが,その影響が相対的に小さい大断面部材 (50x50 cm 以上) では良い一致が見られている。したがって最終值を精度良く推定で きれば，経時的な変化も概ね評価できるものと思われる。

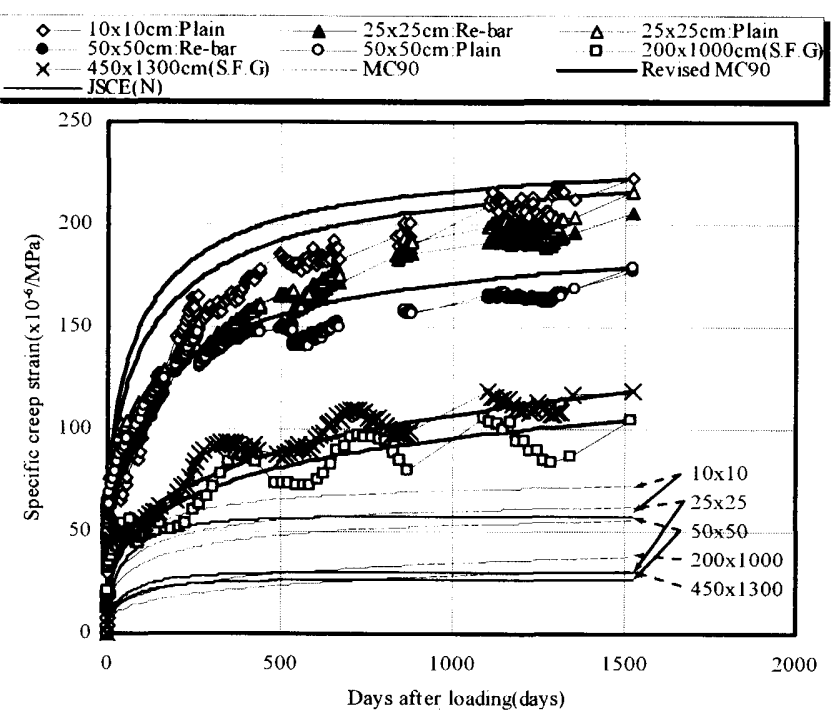

図 9 単位クリープひずみの変化（50MPa）

$130 \mathrm{MPa}$ 試験体のクリープひず夕測定結果を図 10 に示す。図は載荷(材 路 28 日）以降のひずみの変化を示したものである。10x10x40cm, $25 \times 25 \times 160 \mathrm{~cm}$ および $50 \times 50 \times 310 \mathrm{~cm}$ 試験体とも, 単位クリープひずみは概 ね脱型後材齢 900 日で安定する傾向が見られる。10x10x40cm 試験体の単 位クリープひずみは載荷後材龄約 1700 日で約 $25 \times 10^{-6}$ であり, 前述の $50 \mathrm{MPa}$ 試験体と比較して約 $1 / 10$ 程度である。断面寸法が $25 \times 25,50 \times 50 \mathrm{~cm}$ と大きくなるに伴い，寸法に伴う一定の傾向は認められないが，そ の值は $10 \times 10 \times 40 \mathrm{~cm}$ 試験体と比較して若干小さくなる。単位クリープ ひずみの差としてみた場合, 部材寸法の增加に伴う 130MPa コンクリ 一トのひずみの低下は，前述の 50MPa コンクリートのひずみ低下に 比較して極めて小さい。同図には MC900 および JSCE(H) による計 算結果が示されている。本強度はいずれの予測式の適用範囲を超え たものであるため，前述の収縮ひずみ同様，本結果はあくまで参考 値となるが, 実測値に対する JSCE 式予測值および MC90 予測值はい ずれも過大評価となる傾向にある。 


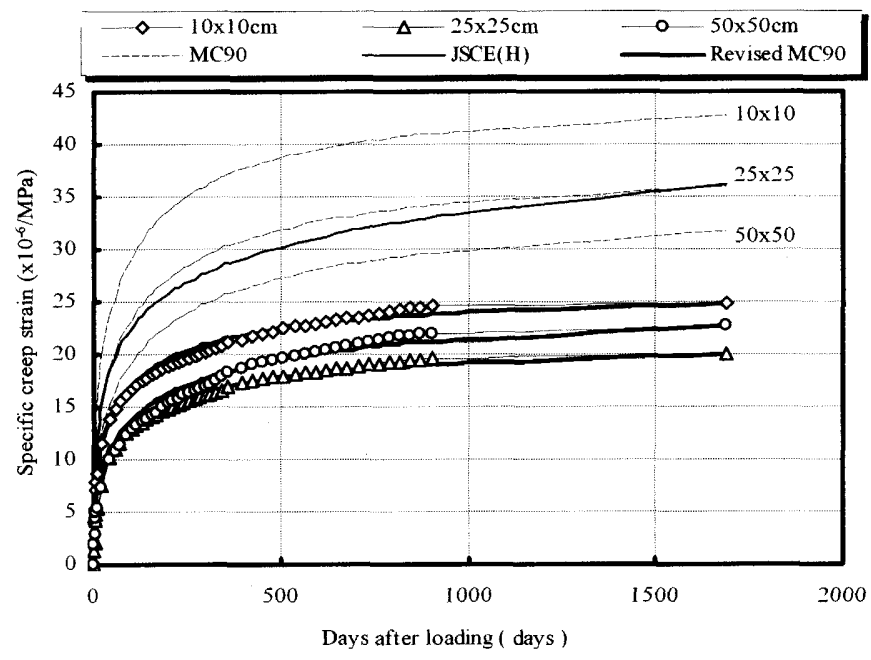

図 10 単位クリープひずみの変化 $(130 \mathrm{MPa})$

\section{3 考察}

\subsection{1 収縮ひずみに及ほす部材寸法の影響}

$50,130 \mathrm{MPa}$ 試験体の収縮ひずみ比(Shrinkage strain ratio) と仮想部材厚 $\mathrm{h}$ もしくは体積表面積比 v/s の関係を図 $11 ， 12$ に示す。収縮ひずみ比にお けるひずみの值は，10x10 cm 試験体の収縮ひずみに対する各試験体の值 の割合として算出した。なお，50MPa については脱型後材龄約 1500 日 時点, 130MPaについては脱型後材齢約 1700 日時点のものである。図 11 は部材断面寸法 50x50cm 試験体までの結果を示したものである。図に示 されるように，強度レベルに関わらず部材断面の増大に伴い，部材中心 部の収縮ひずみはほぼ一定の低下傾向を示し，本検討の範囲内では収縮 ひずみは約 40\%低下する。この低下傾向は MC90，JSCE(適用範囲外の 130MPaは除く)のいずれによっても概ね評価できている。

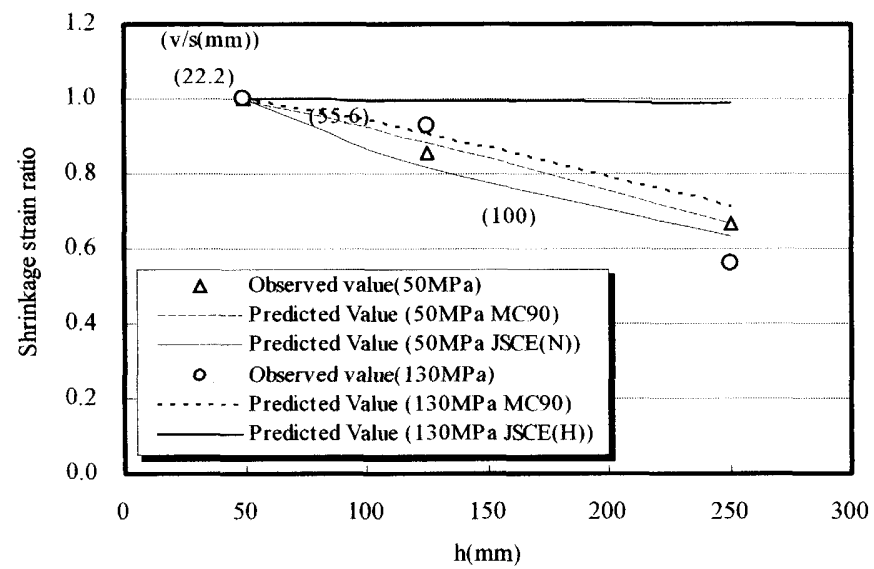

図 11 收縮ひずみの比と寸法の関係（50x50cm まで）

図 12 は, $50 \mathrm{MPa}$ 試験体について，部材断面寸法 $450 \times 1300 \mathrm{~cm}$ 試験体 まで拡張した結果を示したものである。眓に示されるように，部材断面 の増大に伴う中心部の収縮ひずみの低下は著しく，同寸法における収縮 ひずみは $10 \times 10 \mathrm{~cm}$ 試験体の約 5\%（低下量約 95\%）となる。この低下傾 向は MC90 によって概ね評価できている。本部材寸法はJSCE 式の適用 範囲外であるため, ここでは計算結果を示していない。前述した図 7,8 そして既往の文献 ${ }^{8)}$ よ，各種断面コンクリートの収縮ひずみを直接的 に既往の予測式で算定することは困難であるものの，図 11,12 の結果よ り，10x10cm 試験体の収縮ひずみを予め精度よく求めた上で，既往のモ デルコードを用いて部材寸法補正を行うことで，各種断面の収縮ひずみ を精度良く推定することが可能と考えられる。

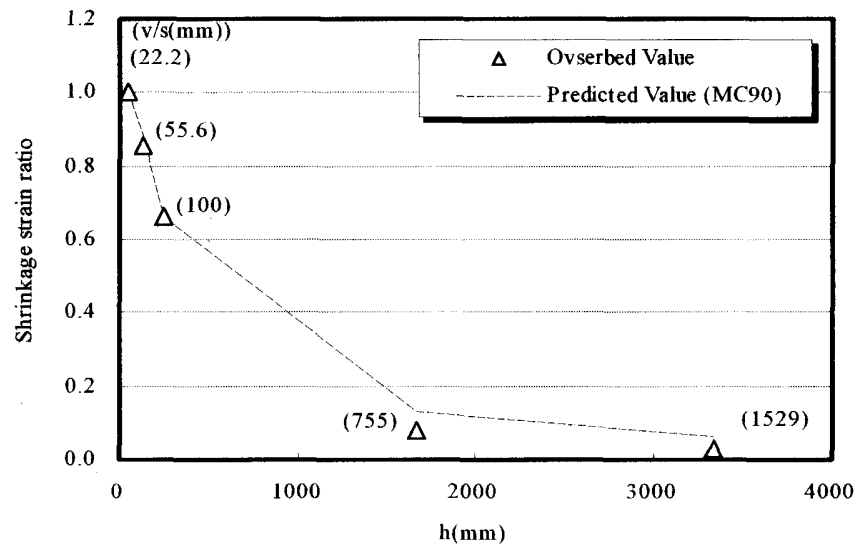

図 12 収縮ひずみの比と寸法の関係（450x1300cm まで）

\section{3.2 単位クリープひずみに及ぼす部材寸法の影警}

$50,130 \mathrm{MPa}$ 試験体の単位クリープひずみ比(Specific creep strain ratio) と仮想部材厚 $\mathrm{h}$ もくは体積表面積比 v/s の関係を図 $13 ， 14$ に示寸。単 位クリープひずみ比におけるひずみの值は，10x10 cm 試験体の単位クリ 一プひずみに対する各試験体の值の割合として算出した。なお，50MPa については載荷後材㱓約 1500 日時点，130MPa については載荷後材龄約 1700 日時点のものである。図 13 は部材断面寸法 $50 \times 50 \mathrm{~cm}$ 試験体までの 結果を示したものである。図に示されるように，強度レベルに関わらず 部材断面の増大に伴い部材中心部の単位クリープひずみは若干の低下傾 向を示す。本検討範囲内ではその大きさは約 10２0\%であり，収縮ひず みのそれ（約 40\%）と比較した低下量は小さい。MC90 は強度レベルに 関らず部材寸法の增大に伴う単位クリープひずみの低下を表現するが， JSCE(N) と(H)では部材寸法の影響の考慮に差異がみられる。測定データ は概ねその中閒に位置する。

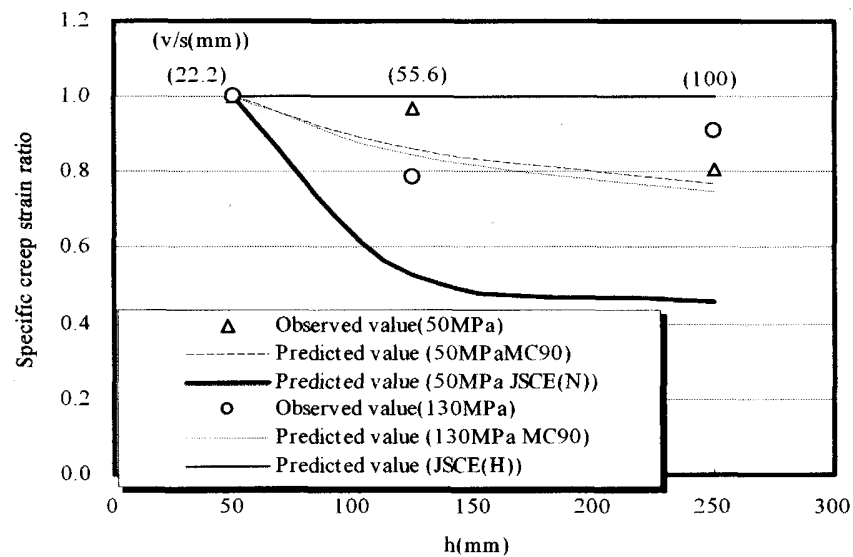

図 13 単位クリープの比と寸法の関係（50x50cm まで）

図 14 は，50MPa 試験体について，部材断面寸法 450x1300cm 試験体 まで搪張した結果を示したものである。図に示されるように，部材断面 の増大に伴う中心部の単位クリープひずみの低下は断面寸法 $50 \mathrm{x} 50 \mathrm{~cm}$ 以 降も進んでおり，本検討範囲内の断面寸法における単位クリープひずみ 低下量は $10 \times 10 \mathrm{~cm}$ 試呀体の約 50\%となり，前述の収縮ひずみのそれ（約 
95\%）と比較して小さい。この低下傾向は MC90 によって概ね評価でき ている。図 9,10より, 各種断面のコンクリートの単位クリープひずみ を直接的に既往の予測式で算定することは困難であるものの，図 13,14 の結果より，10x10cm 試験体の単位クリープひずみを予め精度よく求め た上で，既往のモデルコードを用いて部材寸法補正を行うことで，各種 断面のクリープひずみを精度良く推定することが可能と考えられる。

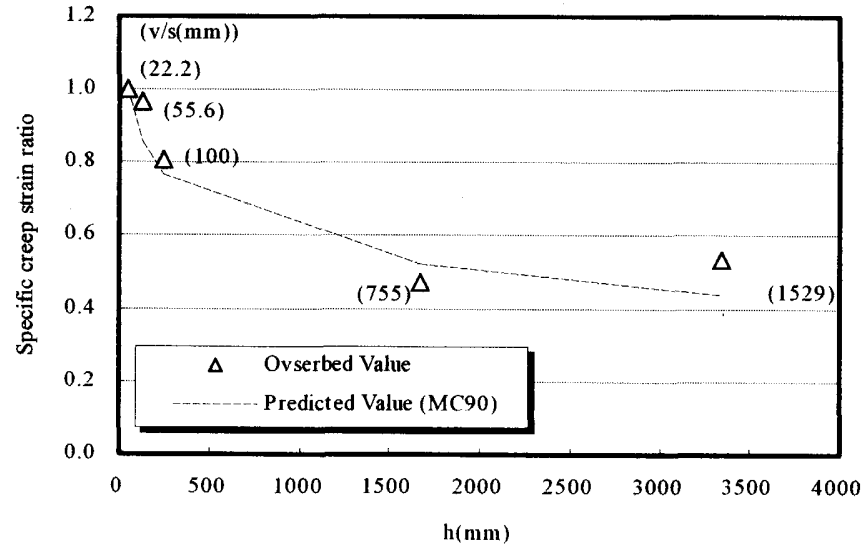

図 14 単位クリープの比と寸法の関係 $(450 \times 1300 \mathrm{~cm}$ まで

\section{3. 既往の実験データに基つくくリープ予測当てはめ式の提案}

\section{1 予測当てはめ式の位置づけ}

10x10cm 試験体の収縮・クリープひずみを予め把握することにより， 各断面の収縮・クリープひずみを概ね精度良く推定できる可能性のある ことを記述した。10x10cm 試験体の収縮ひずみを，短期データに基づい て推定する手法は既に検証している ${ }^{10)}$ 。この方法は管理された等境下で あれば精度面で満足の行くものであり，また，収縮ひずみを测定するこ と自体は実験的な労力をそれほど要しないことから, 比較的実用的なア プローチであると考える。一方, クリープについては実験的な労力が収 縮ひずみのそれよりも相対的に大きいことから，これに関しては調合・ 環境条件より算定できることが望ましい。ここでは既往の実呀でータに 基づくクリープ保数の予測当てはめ方法を検討することにより，広䇶囲 な部材寸法に対応するクリープ予測への道筋について提案を行うもので ある。当てはめの基本式としては, 前述の知見に基づき, MC90 をべー スに検討を行うこととする。

\section{2 既往の実験データの概要}

本研究で検討するクリープ実験データは10x10x40 cm角柱もしくは 10x20cm円柱試験体を用いたものであり，既往の検討"1に用いられたもの を対象とした。実験シリーズとしての総数は約 80 件であり, $10 \times 10 \times 40 \mathrm{~cm}$ しくは $\phi 10 \times 20 \mathrm{~cm}$ 試験体を用いた圧縮クリープを対象と している。クリープの平均材齢はそれぞれ約 250 日であり， 1 シリー ズあたり平均約 $3 \sim 5$ 程度のデータ（データ総数 : 約 399 ）を使用し た。調査対象コンクリートの平均圧縮強度は61 MPa（最大135 MPa, 最小 $20 \mathrm{MPa}$ ) である。なおデータの抽出にあたり, クリープの数值 が記載されているものについてはその值を採用し，図化されている ものについては，該当図より読みとることとした。

\section{3 当てはめ式の提案}

MC90は以下の式により表される。本論では, 図 9,10,13,14 の結果に基 づき, 本式における寸法効果を表す項 $\left(\phi_{\mathrm{RH}}, \beta_{\mathrm{c}}\left(\mathrm{t}-\mathrm{t}_{\mathrm{o}}\right)\right)$ はそのままとし, それ以外の項を実験データにフィットさせることにより，当てはめ式を
構築することとした。

- CEB-FIP1990

$\phi\left(t, t_{o}\right)=\phi_{o} \cdot \beta_{c}\left(t-t_{o}\right)$

ここに,

$\phi\left(t, t_{o}\right)$ :終局クリープ係数(notional creep coefficient)

$\phi_{o}=\phi_{R H} \cdot \beta\left(f_{c m}\right) \cdot \beta\left(t_{o}\right)$

$\phi_{R H}=1+\left(1-R H / R H_{o}\right) /\left[0.46 \cdot\left(h / h_{o}\right)^{1 / 3}\right]$

$\beta\left(f_{c m}\right)=5.3 /\left(f_{c m} / f_{c m o}\right)^{0.5}$

$\beta\left(t_{o}\right)=1 /\left(0.1+\left(t_{o} / t_{1}\right)^{0.2}\right)$

$\beta_{c}\left(t-t_{o}\right)=\left[\left(t-t_{i}\right) / t_{1} /\left(\beta_{H}+\left(t-t_{i}\right) / t_{1}\right)\right]^{p .3}$

$\beta_{H}=150\left[1+\left(1.2 R H / R H_{o}\right)^{18}\right] \cdot h / h_{o}+250 \leq 1500$

$h=2 A_{c} / u$

$\phi\left(\mathrm{t}, \mathrm{t}_{0}\right)$ :材齢 $\mathrm{t}_{0}$ (日) で載荷した材齢 $\mathrm{t}($ 日)でのクリープ俰数

$\beta_{\mathrm{c}}\left(\mathrm{t}-\mathrm{t}_{\mathrm{o}}\right)$ : 時間に依存するクリープの進行を表す係数

$\mathrm{RH}$ : 相対湿度(\%) $\mathrm{RH}_{\mathrm{o}}: 100 \%$

$\mathrm{f}_{\mathrm{cm}}$ : 材齢 28 日圧縮強度 $(\mathrm{MPa}) \mathrm{f}_{\mathrm{cmo}}: 10 \mathrm{MPa}$

$\mathrm{h}:$ 仮想部材厚 $(\mathrm{mm}) \mathrm{A}_{\mathrm{c}}$ : 部材断面積

$\mathbf{u}:$ 部材断面の外気に接する部分の長さ

$\mathrm{h}_{\mathrm{o}}: 100 \mathrm{~mm} \quad \mathrm{t}_{\mathrm{l}}: 1$ (日)

検郡の手順は以下により行う。

(1) 式(2)において当該材齢 $\left(\mathrm{t}_{\mathrm{i}}\right)$ )クリープデータ $\left(\phi\left(\mathrm{t}_{\mathrm{i}}, \mathrm{t}_{\mathrm{o}}\right)\right)$ に対し，下 式(3)により $\phi_{0}$ を推定する。

$\phi_{o}=\phi\left(t_{i}, t_{o}\right) / \beta_{c}\left(t_{i}-t_{o}\right)$

(2) この $\phi_{\mathrm{o}}$ を $\phi_{\mathrm{RH}}$ で除し, 同一載荷材龄 $(28$ 日) のデータについて, $\beta\left(\mathrm{f}_{\mathrm{cm}}\right) /\left(\beta\left(\mathrm{t}_{\mathrm{o}}\right) / \beta(28)\right)$ と $1 /\left(\mathrm{f}_{\mathrm{cm}} / \mathrm{f}_{\mathrm{cmo}}\right)^{0.5}$ の関係を検討寸る。これを図 15 に示す。このデータ群に対して直線回帰を行い, この関係式 を用いて $\beta^{\prime}\left(\mathrm{f}_{\mathrm{cm}}\right)$ とする。

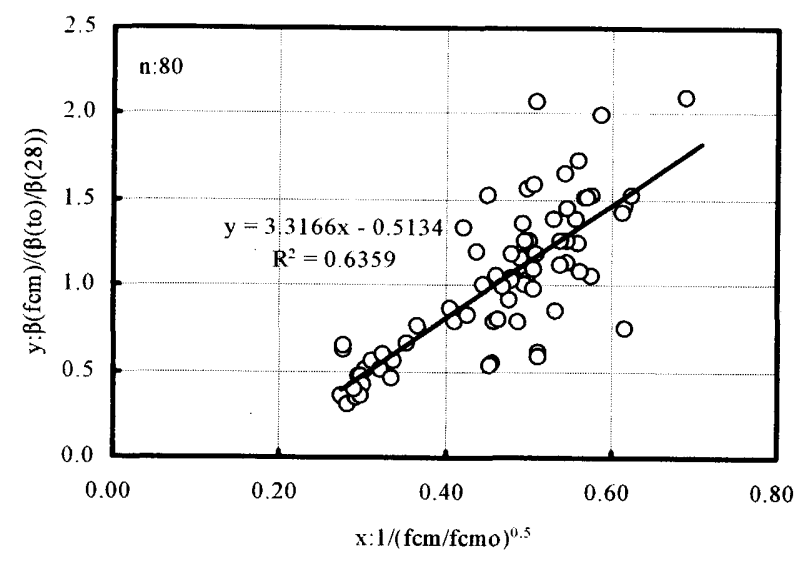

図 $15 \beta\left(\mathrm{f}_{\mathrm{cm}}\right)$ と $1 /(\mathrm{fcm} / \mathrm{fcmo})^{0.5}$ の関係

(3) 同一シリーズで載荷時材齢を変化させた実験データを対象に, (1) の手法で $\phi_{0}$ を推定し，これを $\phi_{R H}$ 及び(2)で得られた式により除す。こ れによって得られた $\beta\left(\mathrm{t}_{0}\right)$ に相当する。載荷材齡 28 日の值に対する比の 逆数と（ $\left.\beta(28) / \beta\left(\mathrm{t}_{0}\right)\right)$ と $\left(\mathrm{t}_{0} / \mathrm{t}_{1}\right)^{0.2}$ の関係を図 16 に示す。このデー夕群 に対して直線回㷌を行い，この関倸式を用いて $\beta$ '(to) とする。 


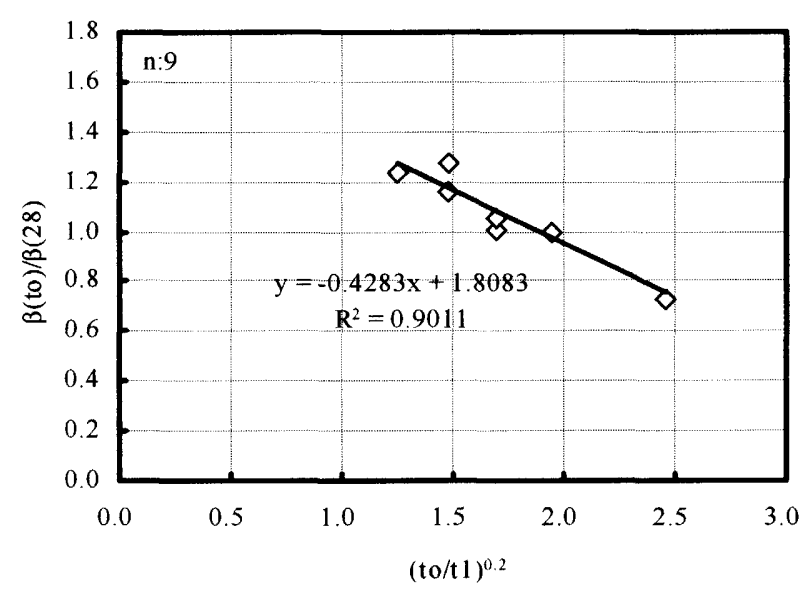

図 $16 \quad(\beta(28) / \beta(\mathrm{to})) \zeta(\mathrm{to} / \mathrm{t} 1)^{0.2}$ の関係

以上より当てはめ式は以下の通りとなる。

$\phi\left(t, t_{o}\right)=\phi_{o} \cdot \beta_{c}\left(t-t_{o}\right)$

$こ こ に$,

$$
\begin{aligned}
& \phi_{o}=\phi_{R H} \cdot \beta^{\prime}\left(f_{c m}\right) \cdot \beta^{\prime}\left(t_{o}\right) \\
& \phi_{R H}=1+\left(1-R H / R H_{o}\right) /\left[0.46 \cdot\left(h / h_{o}\right)^{1 / 3}\right] \\
& \beta^{\prime}\left(f_{c m}\right)=3.32 /\left(\left(f_{c m} / f_{c m o}\right)^{0.5}-0.51\right) \\
& \beta^{\prime}\left(t_{o}\right)=1.81-0.43\left(t_{o} / t_{1}\right)^{0.2}
\end{aligned}
$$

\section{4 実験データとの比較}

式(2)に示す MC90 と当てはめ式(4)による計算値と実験值の比較を図 17,18 に示す。本提案式の強度の適用範曲は, 検討したデータより上限 $130 \mathrm{MPa}$ である。実験データとの適合性は下式に示寸誤差係数(E)により 評価した ${ }^{12)}$ 。図に示すように MC90 では実験值との間に若干の乘離が生 じているが, 上記のデータフィットにより，誤差係数の評価においては 約 24\%適合性が改善されている。しかしながらそれでも図 18 に示寸実 験值と計算值は, 最大 $1 / 2 \sim 2$ 倍程度の範囲で差が生じている。解析上, 乾燥収縮拘束応力の変動に及ぼすクリープ変動の影響の大きさは, 収縮 ひずみのそれと比較して $1 / 10$ 程度であることが示されている ${ }^{13)} も の の ，$ この精度のさらなる改善が今後の課題であると考える。

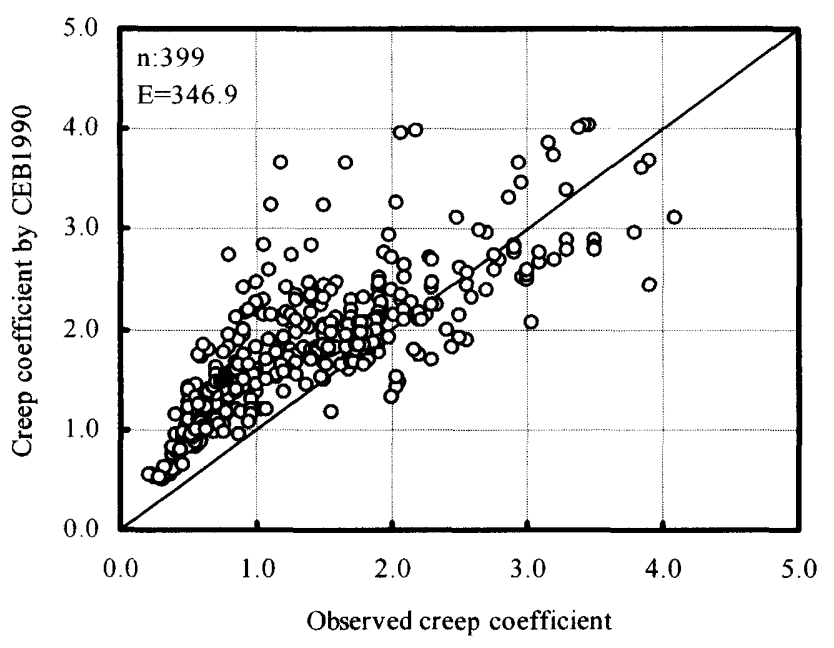

図 17 実験値と計算値の比較（MC90）
$E=\frac{\sum_{i=1}^{n} 1 / \varepsilon_{m i}}{N} \cdot\left[\frac{\sum_{i=1}^{n}\left(\varepsilon_{p i}-\varepsilon_{m i}\right)^{2}}{n}\right]^{0.5} \cdot 100$

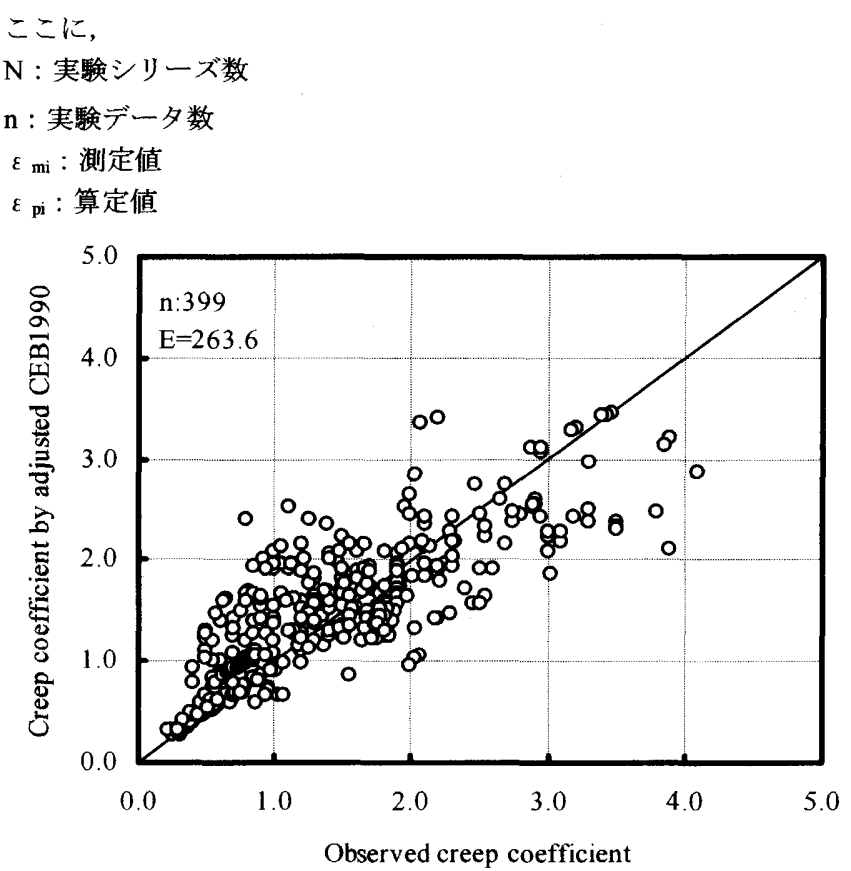

図 18 実験值と計算値の比較（当てはめ式）

\section{4. まとめ}

本研究では, $50 \mathrm{MPa}, 130 \mathrm{MPa}$ 級の 2 種類の強度レベルのコンクリート

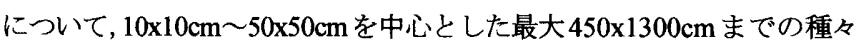
の断面寸法の試験体の約 5 年間にわたるクリープ・収縮ひずみ測定を実 施した。その結果に基づいて，クリープ・収縮ひずみに及ぼす部材寸法 の影響，既往のモデルコードによる寸法効果評価の適用性について検討 を行った。本研究の結果を以下にまとめる。

1）部材寸法が大きくなるほど, クリープ・収縮ひずみは小さくな る。クリープひずみに及ぼす部材寸法の影響は，収縮ひずみに 及ぼす部材寸法の影響と比較して相対的に小さい。

2）単位クリープひずみについてみた場合，部材寸法の増加に伴う $130 \mathrm{MPa}$ 強度レベルコンクリートのひずみの低下は $50 \mathrm{MPa}$ 強度 レベルコンクリートのひずみ低下に比較して極めて小さい。

3) 部材寸法の增加に伴う相対的なクリープ・収縮ひずみの低下傾 向は既往の予測式である CEB-FIP1990 Model Codeにより概ね評価 可能である。

4）以上より，例えば $10 \mathrm{x} 10 \mathrm{~cm}$ 断面の試験体を基淮として，その值を 把握することにより，各種断面のクリープ・収縮ひずみを精度良く 推定することが可能であると考え，本論においてクリープ予測当て はめ式についての提案を行った。

\section{参考文献}

1) CEB-FIP: Model Code 1990, Comite Euro-International du Beton, 1990

2）土木学会 : コンクリート標準示方書 構造性能照査編， 2002.4

3) N.J. Gardner: Design Provisions for Shrinkage and Creep of Concrete, 
ACI SP-194, pp.101-133, 2000.8

4) T.C. Hansen, A.H. Mattock: Influence of Size and Shape of Member on the Shrinkage and Creep of Concrete, Journal of ACI., pp.267-289, 1966.2

5) A. H. Bryant, C. Vadhanavikkit: Creep, Shrinkage-Size, and Age at Loading Effects, ACI Materials Journal, pp.117-123, 1987.

6) 安田正雪他: 大型コンクリート柱部材の圧縮クリープ性状, 日本建 築学会大会学術講演梗概集, pp.1256-1257，1991.9

7) 桝田佳寛他: 高強度コンクリートを用いた柱部材の圧縮クリープ性 状, 日本建筑学会大会学術講演梗概集, pp.1511-1512, 1993.9

8）今本啓一, 山本俊彦: 既往の実験データに基づいたコンクリート の乾燥収縮予測当てはめ式の提案, 日本建築学会構造系論文集, No.552, pp.1-6, 2002.2

9) 武田均他 : 壁状コンクリート構造物中の無応力計のひずみに関 する検討，士木学会第 49 回年次学術講演会, pp.712-713，2004.

10）石井寿美江，今本啓一：短期の実験デー夕に基づくコンクリー 卜の乾燥収縮量の予測, 日本建築学会学術講演梗概集 A-1 材料 施工, pp.115-116， 2003.9

11）日本建築学会 : プレストレスト（鉄筋）コンクリート構造部材 の設計法一現状と将来一, pp.1-9, 2000.4.

12) Neville A.M., Dilger W.H., and Brooks J.J. : Creep of Plain and Structural Concrete, Construction Press, 1983.

13）閑田徹志他：収縮ひび割れ制御に関する性能設計についてーそ の 2 収縮ひび割れ発生の確率モデル，日本建築学会関東支部研 究報告集 I , pp.45-48，2005.3

Appendix 1

鉄筋コンクリート（RC）部材のクリープについて

$\mathrm{RC}$ 部材のクリープ載荷ではコンクリートの単位応力度あたりのク リープ（S(t)）は以下の付式(1)により表すことができる，すなわち，

$S(t)=\left(\varepsilon_{f}-\varepsilon_{f c}\right) / \sigma_{c}(t)$

ここに,

$\sigma_{\mathrm{c}}(\mathrm{t}):$ コンクリートの応力度,

$\varepsilon_{\mathrm{f}}:$ 無載荷の RC 部材のひずみ

$\varepsilon_{\mathrm{fc}}$ : 載荷された RC 部材のひずみ

この状況で，コンクリート自体のクリープによりコンクリートと鉄 筋の念力分担率が変化することが考えられる $\left(\sigma_{\mathrm{c}}(\mathrm{t})\right.$ が時間ともに変 化する)。今, RC 部材のクリープ載荷試験において, 以下の仮定を 設ける。

1. RC 部材への載荷荷重は，鉄筋とコンクリートに作用する荷重の 和である。

2. クリープ載荷において, 鉄筋ひずみとコンクリートひずみは等し い。

この場合，コンクリートの応力度 $\sigma_{\mathrm{c}}(\mathrm{t})$ ，は，1 の力の釣り合いおよ び 2 のひずみの適合条件より，付式(2)で表すことができる。

$\sigma_{c}(t)=P /\left(A_{c}+E_{s} / E_{e c}(t) \cdot A_{s}\right)$
ここに,

$\sigma_{\mathrm{c}}(\mathrm{t})$ : コンクリートの応力度

$\mathrm{P}:$ : 載荷荷重 $(\mathrm{kN})$

Ac : コンクリート断面積 $\left(\mathrm{mm}^{2}\right)$

Es : 鉄筋ヤング係数 $\left(\mathrm{kN} / \mathrm{mm}^{2}\right)$

$\operatorname{Eec}(\mathrm{t})$ : コンクリートのクリープを考慮したヤング係数 $\left(\mathrm{kN} / \mathrm{mm}^{2}\right)$

$E_{e c}(t)=E_{c} /\left(1+\phi\left(t, t_{o}\right)\right)$

$\phi\left(\mathrm{t}, \mathrm{t}_{0}\right)$ : 材齢 $\mathrm{t}_{0}($ 日) で載荷した材㱓 $\mathrm{t}($ 日)でのクリープ係数

As : 鉄筋断面積 $\left(\mathrm{mm}^{2}\right)$

今, 本論で検討した $50 \mathrm{MPa}$ 強度レベルの断面 $50 \times 50 \mathrm{cmRC}$ 部材につ いて，鉄筋比をパラメータ（0３\%）に取ったコンクリート応力度の 変化及び単位クリープひずみの変化を付図 1 および 2 に示す。コン クリートの応力度は鉄筋の存在により减少（鉄筋に応力が移行）し, 結果として単位クリープひずみは增加する傾向にある。しかしなが ら本研究で対象とする鉄筋比 $0.32 \%$ では鉄筋比 $0 \%$ （無笳）と比較し てその変化は図に示すように小さく，これが本実験でも無筋部材と $\mathrm{RC}$ 部材でクリープに大きな差を生じなかった一因と考えられる。以 上の考察に基づき, 本実験では $\mathrm{RC}$ 部材のクリープをほぼ無筋部材の それと同等として取り扱うこととした。

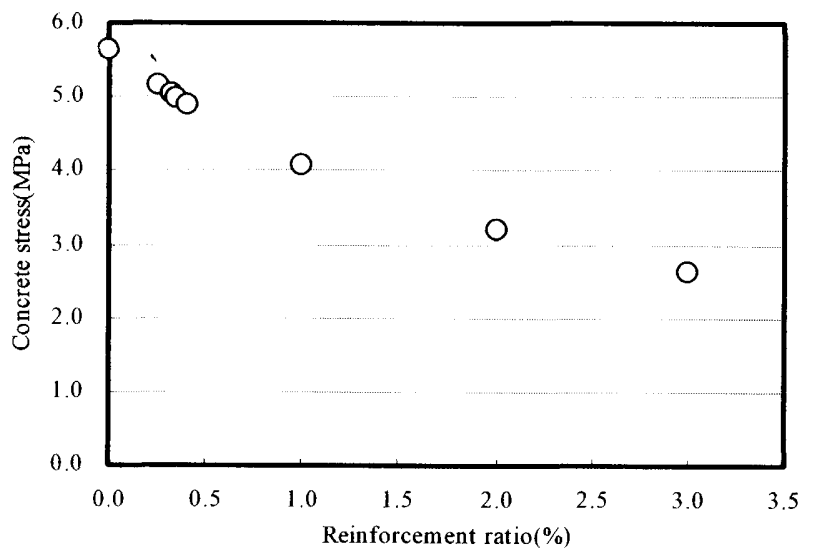

付図 1 コンクリート応力度の変化 $(50 \times 50 \mathrm{~cm}$ 部材 $)$

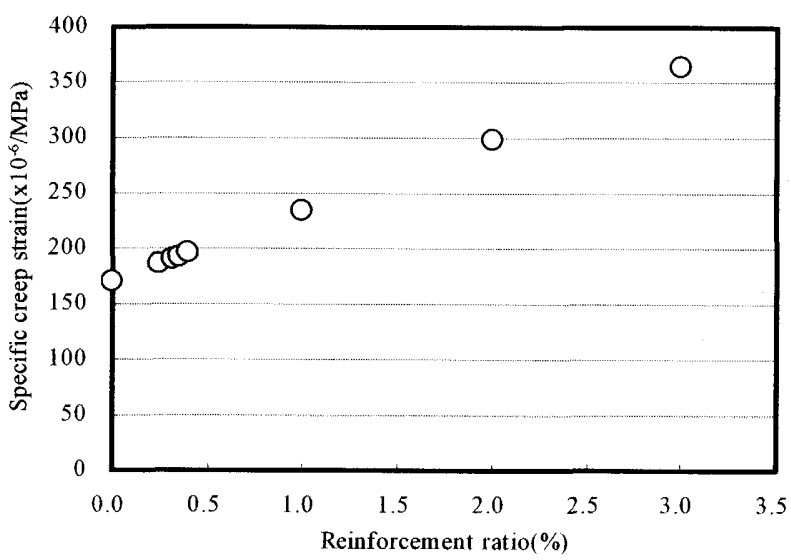

付図 2 単位クリープひずみの変化（50x50cm 部材）

（2004年12月 10 日原稿受理， 2005 年 3 月 23 日操用決定） 